\title{
Comparison of R.C.C. And Composite Multistoried Buildings
}

\author{
Deepak M Jirage, Prof. V.G. Sayagavi, Prof. N.G. Gore, Prof.P.J.Salunke
}

\begin{abstract}
Steel concrete composite construction has gained wide acceptance world wide as an alternative to pure steel and pure concrete construction. The use of steel in construction industry is very low in India compared to many developing countries. There is a great potential for increasing the volume of steel in construction, especially in the current development needs India and not using steel as an alternative construction material and not using it where it is economical is a heavy loss for the country. In the present work steel concrete composite with RCC options are considered for comparative study of G+15 story building which is situated in earthquake zone-IV and for earthquake loading, the provisions of IS: 1893 (Part1)-2002 is considered. A three dimensional modelling and analysis of the structure are carried out with the help of ETAB software.
\end{abstract}

Index terms: Composite column, Composite beam, shear connectors, ETAB Software

\section{INTRODUCTION}

Composite structures can be defined as the structures in which composite sections made up of two different types of materials such as steel and concrete are used for beams, columns. This paper includes comparative study of R.C.C. with Steel Concrete Composite G+ 15 story building which situated in earthquake zone IV. Equivalent Static Method and Response Spectrum Method of Analysis is used.. Comparative study includes deflection, story drift, base shear, stiffness. It is found that composite structure is more economical and speedy than R.C.C. structure.

\section{COMPSOITE CONSTRUCTION}

In today's modern era of innovation, two materials widely and inevitably used as construction material are steel concrete for structures ranging from buildings to bridges. The failure of many multi-storied and low- rise RCC and masonry buildings due to earthquake has forced the structural engineers to look for the alternative method of construction having lesser depth which saves the material cost. The use of Steel in construction industry is very low in India compared to many developing countries.

Prof V.G.Sayagavi (Guide) Civil Engg Dept., MGM's College of Engg and Technology, Navi Mumbai

Prof N.G.Gore (Co-Guide) Civil Engg Dept., MGM's College of Engg and Technology, Navi Mumbai

Prof P.J.Salunke (Guide) Civil Engg Dept., MGM's College of Engg and Technology, Navi Mumbai

\section{Elements of Composite Construction}

\section{A. Composite Column}

Steel concrete composite column is a compression member, comprising either of a concrete encased hot rolled steel section or a concrete filled hollow section of hot rolled steel.
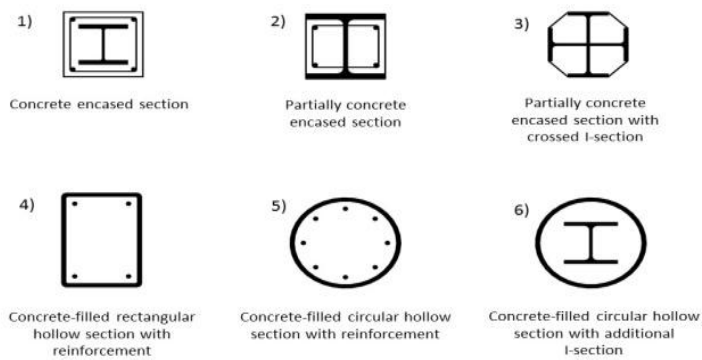

Fig.1. Composite Column

\section{B. Composite Beam}

A composite beam is a steel beam or partially encased beam which is mainly subjected to bending and it supports the composite deck slab.
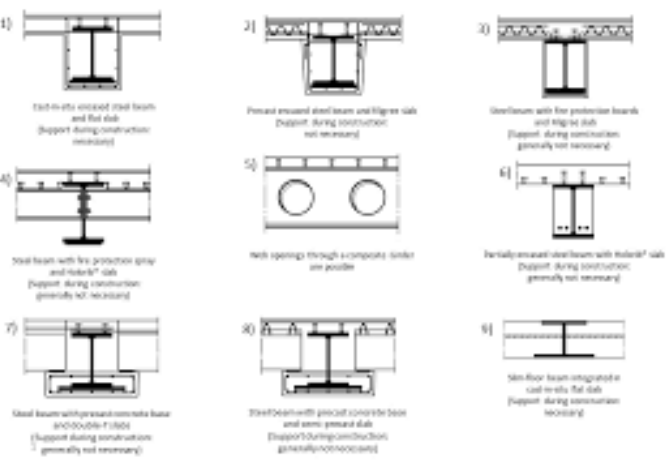

Fig.2. Composite Beam

\section{Profile Deck}

Composite floors using profiled sheet decking have become very popular in the West for high-rise buildings. Composite deck slabs are generally competitive where the concrete floor has to 
be completed quickly and where medium level of fire protection to steel work is sufficient. There is presently no Indian standard covering thedesign of composite floor systems using profiled sheeting.

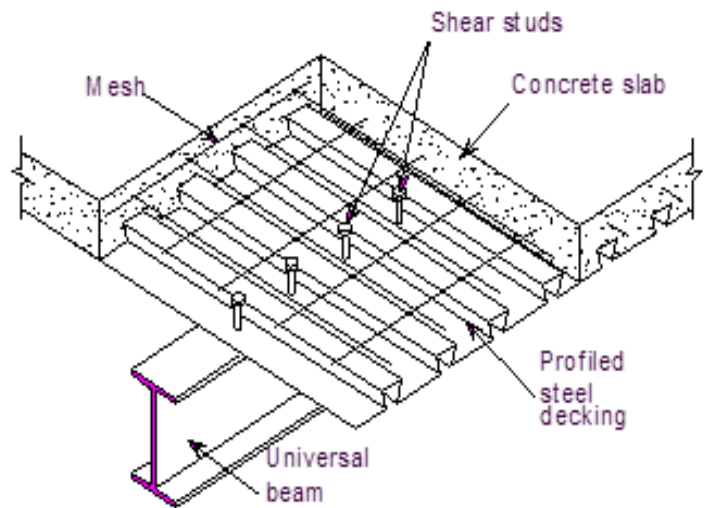

Fig.3. Composite Slab

\section{Shear Connector}

connectors are steel elements such as studs, bars, spiral or another similar devices welded to the top flange of the steel section and intended to transmit the horizontal shear between the steel section and the cast in-situ concrete and also to prevent vertical separation at the interface

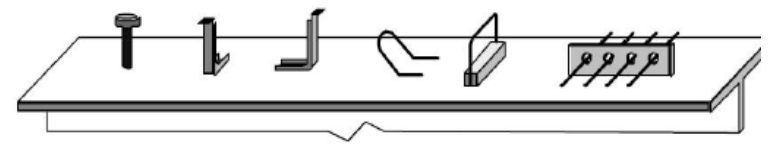

Fig.4. Shear Connector

Advantages of composite construction

- Permits easy structural repairs/ modification.

- Lighter construction

- Good fire resistance

- Enables easy construction scheduling in congested sites.

- Composite sections have higher stiffness than the corresponding steel sections and thus the deflection is lesser.

\section{BUILDI NG DETAILS}

The building considered here is an residential building having $\mathrm{G}+15$ storied located in seismic zone IV and for earthquake loading, the provisions of the IS:1893(Part1)-2002 is considered. The wind velocity $44 \mathrm{~m} / \mathrm{s}$. The plan of building is shown in fig. the building is planned to facilitate the basic requirements of an residential building. The plan dimension of the building is $20 \times 20 \mathrm{~m}$. Height of each storey for composite and RCC is $3.2 \mathrm{~m}$. The floor plans were divided into five by six bays in such a way that center to center distance between two grids is 4 meters by 4 meters respectively. The study is carried out on the same building plan for RCC and composite construction with some basic assumptions made for deciding preliminary sections of both the structures.

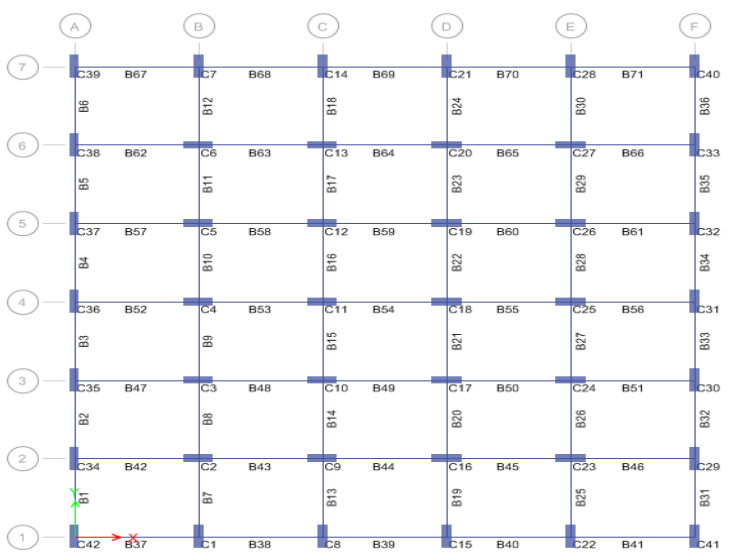

Fig.5. Typical Floor Plan

Table I: Data for RCC and Composite Structure

\begin{tabular}{|c|c|}
\hline Plan dimension & $20 \mathrm{~m} \times 20 \mathrm{~m}$ \\
\hline Height of each storey & $3.2 \mathrm{~m}$ \\
\hline Height of parapet & $1 . .2 \mathrm{~m}$ \\
\hline Thickness of slab & $0.150 \mathrm{~m}$ \\
\hline Thickness of external wall & $0.230 \mathrm{~m}$ \\
\hline Thickness of internal wall & $0.150 \mathrm{~m}$ \\
\hline Floor Finish & $1 \mathrm{KN} / \mathrm{m}^{2}$ \\
\hline Live Load & $1.5 \mathrm{KN} / \mathrm{m}^{2}$ \\
\hline Grade of reinforcing steel & $\mathrm{Fe} 500$ \\
\hline Density of concrete & $25 \mathrm{KN} / \mathrm{m}^{3}$ \\
\hline Density of brick & $18 \mathrm{KN} / \mathrm{m}^{3}$ \\
\hline Grade of concrete for beams & M 20 \\
\hline $\begin{array}{c}\text { Grade of concrete for } \\
\text { columns }\end{array}$ & M 20 \\
\hline Grade of concrete for slab & M20 \\
\hline Seismic zone & 0.16 \\
\hline Soil condition & Medium soil \\
\hline Wind speed & $44 \mathrm{~m} / \mathrm{s}$ \\
\hline Importance factor & 1 \\
\hline Zone factor & IV \\
\hline Damping ratio & $5 \%$ \\
\hline Column size R.C.C & $\begin{array}{c}300 \mathrm{~mm} \mathrm{X} 1100 \\
\mathrm{~mm}\end{array}$ \\
\hline Beam size R.C.C. & $230 \mathrm{~mm} \mathrm{X} 700 \mathrm{~mm}$ \\
\hline Column size Composite & $\begin{array}{c}600 \mathrm{~mm} \mathrm{X} \mathrm{600mm} \\
\text { ISHB } 400\end{array}$ \\
\hline \multirow[t]{2}{*}{ Beam size Composite } & $\begin{array}{l}\text { Primary } \\
\text { ISWB } 400\end{array}$ \\
\hline & $\begin{array}{l}\text { Secondary } \\
\text { ISMB } 250\end{array}$ \\
\hline
\end{tabular}

\section{LOAD COMBINATIONS}

The gravity loads and earthquake loads will be taken for analysis. The basic loads are Dead loads (DL), Imposed load (LL), Earthquake load (EQ) along $\mathrm{X}$ and $\mathrm{Y}$ in positive and negative direction. As per IS 1893 (Part I): 2002 Clause no. 6.3.1.2, the following 
Earthquake load cases have to be considered for analysis.
$1.5(\mathrm{DL}+\mathrm{LL})$
$0.9 \mathrm{DL} \pm 1.5 \mathrm{EQ}$
$1.5(\mathrm{DL} \pm \mathrm{WL})$
$1.5(\mathrm{DL} \pm \mathrm{EQ})$
$0.9 \mathrm{DL} \pm 1.5 \mathrm{WL}$
1.2(DL $+\mathrm{LL} \pm \mathrm{WL})$
$1.2(\mathrm{DL}+\mathrm{LL} \pm \mathrm{EQ})$

\section{ANALYSIS OF BUILDING}

The explained 3D building model is analysed using Equivalent Static Method and Response Spectrum Method. Different parameters such as deflection, story drift, base shear and time period are studied for the models. The dead load and live load are considered as per IS-875(part 1 \&2) and wind load is considered as per IS-875(part 3).For earthquake loading IS: 1893 (Part1)-2002 is used.

\section{RESULT}

A. Weight of Structure for RCC and Composite

Table II : Variation of Wt. of Structure

\begin{tabular}{|c|c|}
\hline \multicolumn{2}{|c|}{ WEIGHT OF STRUCTURES IN KN } \\
\hline RCC & 96576.25 \\
\hline COMPSOITE & 72012.54 \\
\hline
\end{tabular}

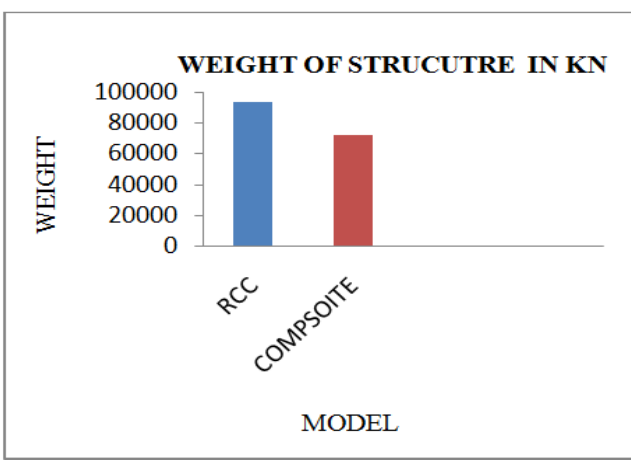

Fig.6.Graph for Wt. of Structure

B. Base Shear of RCC and Composite

Table III: Variation of base shear

\begin{tabular}{|c|c|}
\hline \multicolumn{2}{|c|}{ BASE SHEAR IN X DIRECTION } \\
\hline RCC & $2895.76 \mathrm{KN}$ \\
\hline COMPOSITE & $2215.29 \mathrm{KN}$ \\
\hline
\end{tabular}

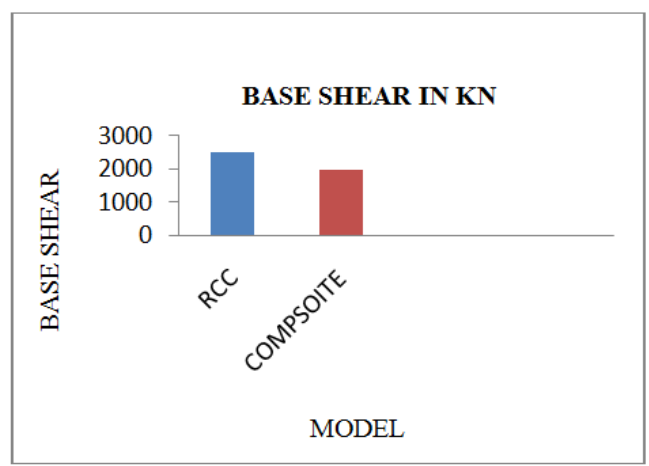

Fig.7.Graph for Base Shear
C. Axial force on Corner Column RCC and Composite

Table IV: Variation of Axial force

\begin{tabular}{|c|c|}
\hline AXIAL FORCE ON CORNER COLUMNS IN KN \\
\hline RCC & 4529 \\
\hline COMPSOITE & 3951 \\
\hline
\end{tabular}

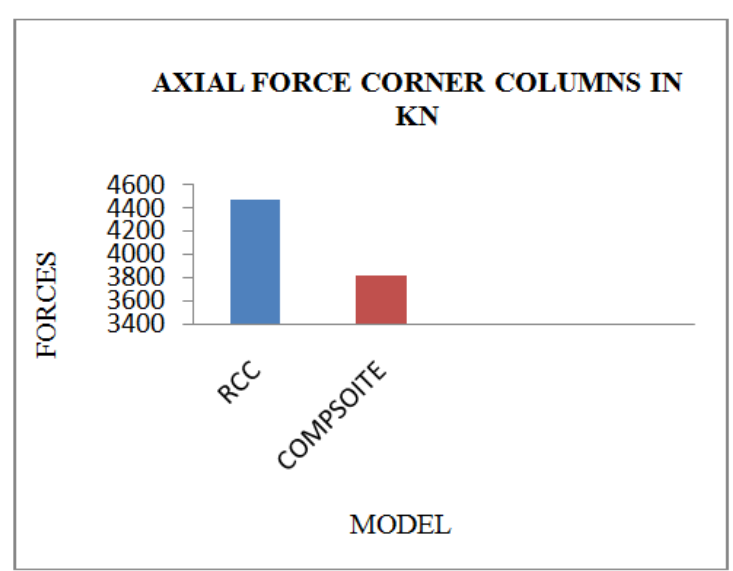

Fig.8.Graph for Axial force in Corner column

D. Time period for RCC and Composite

Table V: Variation of Time Period

\begin{tabular}{|c|c|}
\hline \multicolumn{2}{|c|}{ TIME PERIOD IN SEC. } \\
\hline RCC & 2.83 \\
\hline COMPOSITE & 3.29 \\
\hline
\end{tabular}

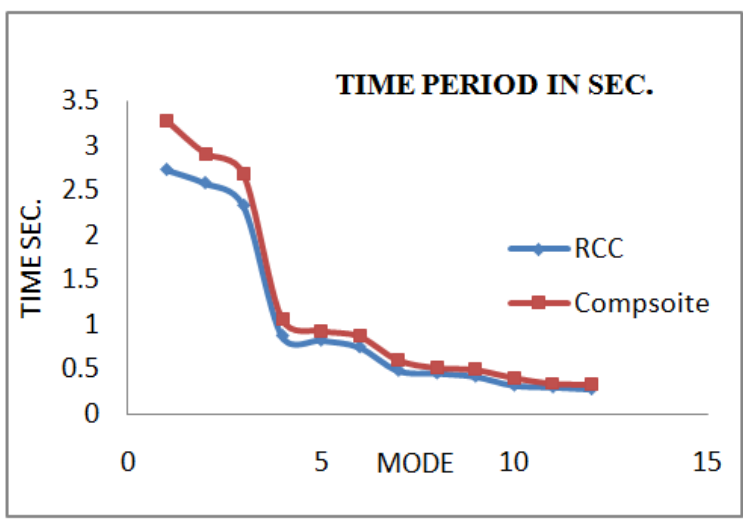

Fig.9.Graph for Time Period

E. Story Displacement of RCC and Composite

Table VI: Variation of Story Displacement STORY DISPLACMENT IN MM X DIRECTION

\begin{tabular}{|c|c|c|}
\hline STORY NO. & RCC & COMPOSITE \\
\hline 15 & 42.35 & 47.25 \\
\hline 10 & 32.18 & 35.28 \\
\hline 5 & 12.81 & 15.29 \\
\hline
\end{tabular}




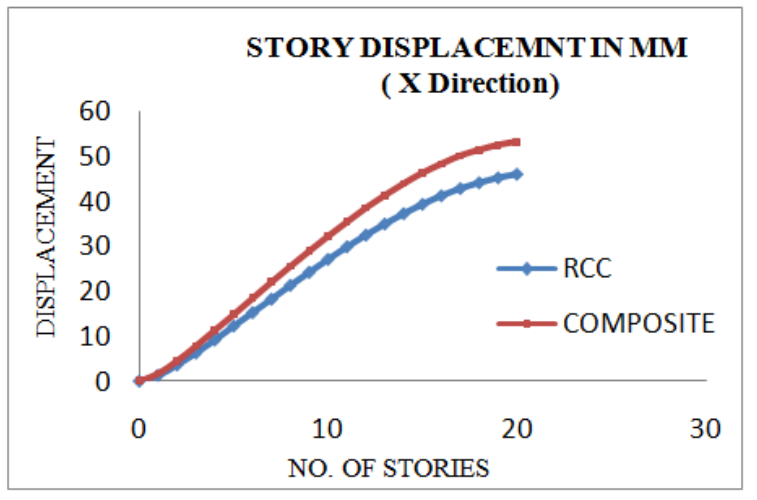

Fig.10.Graph for Story Displacement

\section{CONCLUSION}

1. From table II .it is clear that the wt. of Composite structure is reduced by $33 \%$ as compared with RCC Structure.

2. From table III. it is clear that the base shear of Composite structure is reduced by $15 \%$ as compared with RCC structure.

3. From table IV. It is clear that the axial force in Composite structure is less as compare with RCC by $15 \%$, because the self wt. of the RCC structure is more.

4. From table V. It is clear that the time period of Composite is more as compare to RCC.

5. The displacement of Composite structure is more as compare with RCC. Deflection is within permissible limit.

6. Composite structure is more economical than the RCC structure

7. Time required for construction of composite structure is less as compare with RCC structure because no form work is required.

\section{REFERNCENS}

[1] D. R. Panchal, P.M.Marathe: 'Comparative Study of R.C.C, Steel and Composite (G+30 Storey) Ahmadabad (2011).

[2] Anish N. Shah, Dr. P. S. Pajgade, "Comparison of RCC and Composite Multistoried Buildings", International Journal of Engineering Research and Application (IJERA), ISSN: 2248-9622, Vol.3, Issue 2, March-April 2013, pp.534-539.

[3] A.Y. Elghazouli: 'Behavior of steel composite member subjected to earthquake loading', (2004).

[4] Mote.A.N: 'Experimental and Simulation of Columns of Steel- section Encased in Reinforced Concrete', PP-105-108 OIJSE (2013).

[5] IS 456-2000, 'Indian Standard code of practice for Plain and Reinforced concrete', Bureau of Indian Standards, New Delhi, India.
[6] IS 875(part1 to 5):1987, 'Code of Practice for design loads for buildings and structures', Bureau of Indian Standards, New Delhi, India.

[7] IS 1893-2002, 'Criteria for Earthquake Resistant Design of Structure'.

[8] IS 11384:1985, 'Code of Practice for Design of Composite Structure', Bureau of Indian Standards, New Delhi, India.

[9] Euro code 4: 'Design of Composite Steel and Concrete Structures'. 